\title{
Estimation of the Interaction Effect Between Salinity and Growth Regulators on Salt Tolerance of Two Bread Wheat Cultivars
}

\author{
Ibrahim I. Al-Mishhadani ${ }^{1}$, Eman N. Ismail ${ }^{1}$, Khudhair A. Jaddoa ${ }^{2}$, Duha M. Majeed ${ }^{1}$, \\ Omer A. Mohammed ${ }^{1}$ \\ ${ }^{1}$ Biotechnology research center, Al-Nahrain University ,Baghdad, Iraq \\ ${ }^{2}$ Baghdad University, College of Agriculture, Department of Field Crop Sciences, Baghdad, Iraq \\ Email address: \\ hassanir1955@yahoo.com (I. I. Al-Mishhadani), khdhayerjaddoa@yahoo.com (K. A. Jaddoa)
}

\section{To cite this article:}

Ibrahim I. Al-Mishhadani, Eman N. Ismail, Khudhair A. Jaddoa, Duha M. Majeed, Omer A. Mohammed. Estimation of the Interaction Effect Between Salinity and Growth Regulators on Salt Tolerance of Two Bread Wheat Cultivars. International Journal of Applied Agricultural Sciences. Vol. 1, No. 4, 2015, pp. 95-101.doi: 10.11648/j.ijaas.20150104.12

\begin{abstract}
Absract: The objective of this study is to investigate the effect of the interaction between salinity and plant growth regulators (Kinetin and gibberellin) on the salt tolerance of two bread wheat cultivars (Dijilla) and (Tamooze-2) under salinity conditions. The present study was conducted to assess the effects of Kinetin and gibberellin on plant dry matters (shoots and roots), chlorophyll content and stability in upper leaves, salt tolerance index, and organic contents in plant leaves of the two cultivars grown in salinized soils at two levels $(0$ and $16 \mathrm{ds} / \mathrm{m})$. Seeds of both cultivars were sown in plastic pots which filled with the salinized soil in glass house during 2014-2015 sessions. Selected cultivar gave the highest dry matters, chlorophyll content and stability, and salt tolerance index under salinity condition as compared with local cultivar. Also the selected cultivar had the highest organic compounds in their leaves, especially under salinity condition. Both plant growth regulators were effective in increasing all the measured characters of both cultivars under non-saline condition but at salinity condition were effective in selected cultivar only. The Kinetin was more effective than the gibberellin in their effect on the salt tolerance of the plants under saline condition. Generally under these conditions the selected cultivar (Dijilla) was more salt tolerance than local cultivar.
\end{abstract}

Keywords: Wheat, Salinity, Salt Tolerance, Plant Growth Regulars

\section{Introduction}

Salt stress is a big problem in crop production, and secondary salinization in soil of protected cultivation has become one of major factors adversely affecting horticultural crops. Salt stress affects the physiological processes in plant cells. As a result, virtually reduces their productivity and adversely affects their product quality (1).

Photosynthesis of plant is one of the primary processes more affected by a-biotic stresses, which more correlated with the shoot and root growth. Additionally, plant pigments such as chlorophyll are critical to the function and health of plants, and the concentrations of these pigments depend on the species and the surrounding environmental factors (2).Aldesuquy and Gaber(3) found that seawater at $25 \%$ induced significant reduction in soluble, insoluble and total photosynthates as well as ratio of soluble/insoluble photosynthates during growth and development of Vicia faba plants. Salinity adversely affects plant growth and development (4), enzyme activity (5). DNA, RNA protein synthesis (6) and mitosis (7).

Genetic variations in salt tolerance between species and cultivars are used to improve salt tolerance of wheat cultivars which gave more attention by the breeders to overcome salinity problems (8). The development of the technology and biotechnology technique is important achievement obtained providing a possibility to induce new salt tolerant cultivars effectively to reduce the adverse effects of salinity on plant growth and production in the most regions of the world. Plant breeders $(9 ; 4 ; 10 ; 8$ and 11) have made significant achievements improving numbers of salt tolerant cultivars through plant breeding programs.

Cytokinins are important for plant growth and development including cell division, apical dominance, root formation, leaf senescence, stomatal behavior and chloroplast 
development (12). Roshotte et al. (13) suggest that Cytokinins modulate developmental processes in plants under environments stresses. Auxins and Cytokinins are important in plant growth because they interact in several physiological and developmental processes (14). On the other hand, Biddington and Thomas(15)reported that the differences in Cytokinins structure are likely to affect the function of the growth regulator. Plant growth regulators (PGRs) have been successfully applied to reduce the adversely effect of salinity on germination and growth of a number of species (16 and 17). Therefore, Gadallah (16) reported that at optimal concentrations of cytokinins have more beneficial effects on germination, growth, and yield of wheat under salinity conditions. PGRs could be the possible factors involved in priming - induced salt tolerance in plants. Therefore, pre-sowing seeds with cytokinins could regulate the changes in hormonal balance which induced by salt stress in wheat plants by interacting with other hormones(18). Also when plant exposed to salinity with application of Gibberellin, plant hormone and organic matter increased and caused biochemical, physiological and morphological changes and then increased the salt tolerance of plant under salinity conditions (19). Thus, the objectives of the present study are:-

1. Estimation of salt tolerance of selected wheat cultivar (Dijilla) as compared with local cultivar (Tamooze-2).

2. Evaluate the effect of plant growth regulators (Kinetin and Gibberellins) on the plant growth, chlorophyll content in leaves, and salt tolerance of the selected and local cultivars grown under normal and salinity conditions.

3. Studying the effect of the interaction of salinity and PGRs on organic compounds in the leaves of the selected and local cultivars.

\section{Materials and Methods}

Effect of plant growth regulators on salt tolerance of selected and local cultivars were examined in saline soils experiment having two salt concentrations $\left(0\right.$ and $\left.16 \mathrm{ds}^{-1} \mathrm{~m}\right)$.
This selected cultivar was derived from plant breeding programs after 6 cycles of exposure and selection under high salinity levels of drainage water $\left(30 \mathrm{ds}^{-1} \mathrm{~m}\right)$. Salinity level was prepared by mixed two kind of soils differed only in their saline degree (EC). Using electrical conductivity meter to determine the degree of the above level. The experiment was carried out in plastic pots, which filled with salinized soils ( $3 \mathrm{Kg}$ in each pot). The pots were set up in a glass house in completely randomized design with three blocks, each pot contained one observation. The total of pots was 36 (2cultivar $\times 2$ saline level $\times 3$ plantgrowth regulator $\times 3$ blocks), 8 seeds of each cultivar were sown on each pot. All treatments were carried out during growth stages. Seeds and plants were watered with tap water (300 mill/pot) according to the field capacity. Plant growth regulators (PGRs $600 \mathrm{mg}$. $\left.{ }^{1} \mathrm{~L}\right)$ treatments were applied on shoots of all observations after 75 days from the sowing date. Plant growth regulators were sprayed on the shoots once only. The chlorophyll content in the upper leaves was measured at one week before the harvested date by using chlorophyll meter. Plants observation were measured after 4 month from the sowing date and 45 days from the plant growth regulators application. The organic components contents in the leaves of both cultivars at each salt level and PGR treatment were estimated according to the methods as mentioned in Al-Mishhadani, (2015). The following characters were measured after oven drying for 3 days at $70{ }^{\circ} \mathrm{C}$.

1. Shoot and root dry weights (g).

2. Chlorophyll content in the upper leaves.

3. Organic compounds content in the leaves.

4. Salt tolerance index $(\mathrm{ST} 1)=\frac{y p i X y s i}{y p i^{2}}$

ypi $=$ shoot dry weight of control treatment.

ysi $=$ shoot dry weight of saline treatment.

5. Chlorophyll stability index

$=\frac{\text { chlorophyll content in salinity treatment }}{\text { chlorophyll content in control treatment }} \times 100$

The data were subjected to analysis of variance according to the experimental design (Table 1).

Table 1. Mean squares (M.S) and calculated F.of selected and local wheat cultivars characters treated with salinity and plant growth regulators (PGR).

\begin{tabular}{|c|c|c|c|c|c|c|}
\hline \multirow[b]{2}{*}{ S.O.V. } & \multicolumn{2}{|c|}{ Shoot dry weight } & \multicolumn{2}{|c|}{ Root dry weight } & \multicolumn{2}{|c|}{ Chlorophyll--- } \\
\hline & M.S. & F.cal. & M.S. & F.cal. & M.S. & F.cal. \\
\hline Cultivars & 71.17 & $551.17 * * *$ & 28.32 & $1490.5^{* * *}$ & 3823.155 & $4142.1 * * *$ \\
\hline Salinity & 6.85 & $53.02 * * *$ & 0.103 & $5.42 *$ & 505.725 & $547.91 * * *$ \\
\hline PGR & 9.215 & $71.43 * * *$ & 6.56 & $345.26 * * *$ & 134.26 & $145.46 * * *$ \\
\hline Cultivars $\times$ Salinity & 23.72 & $183.88 * * *$ & 5.341 & $281.11 * * *$ & 2144.5 & $2323.4 * * *$ \\
\hline Cultivars $\times$ PGR & 5.93 & $45.97 * * *$ & 6.377 & $335.63 * * *$ & 17.46 & $18.92 * * *$ \\
\hline Salinity $\times$ PGR & 1.39 & $10.78 * * *$ & 1.96 & $103.2 * * *$ & 8.38 & $9.08 * * *$ \\
\hline Error & 0.129 & & 0.019 & & 0.923 & \\
\hline
\end{tabular}

\section{Results}

\subsection{Shoot and Root Dry Weights}

As compared with control (no salinity), $16 \mathrm{ds}^{-1} \mathrm{~m}$ salinized soils caused a significant decrease in the shoots and roots dry weights of plants (Table 1). The cultivars were differed significantly in their shoots and roots dry weights, the dry weights of both characters of selected cultivar (Dijilla) were much higher than those of the local cultivar (Tamooze-2) especially at high salinity level (Table 2, 3). The results of the ANOVA (Table 1) showed that the plant growth 
regulators also differed significantly in their effects $(P \geq 0.01)$ and the interactions between salt $X$ cultivars and salt X PGR also were significant. This reflects that the behavior of cultivars and the PGR effect under salinity condition (16 ds. ${ }^{1} \mathrm{~m}$ ) differed significantly as compared with those under non salinity condition $\left(0 \mathrm{ds}^{-1} \mathrm{~m}\right)$. Therefore, the selected cultivar (Dijilla) gave more shoots and roots dry weight than the local cultivar (Tamooze-2) under salinity condition $\left(16 \mathrm{ds}^{-1} \mathrm{~m}\right)$ and when the PGRs were applied. The PGR (Kinetin)was more effective than Gibberellin on the shoots and roots dry weight under the same salinity condition (Table 2, 3). The results in Table 1 showed that the interaction (cultivars X PGR X salt) was significant at $\mathrm{P} \geq 0.01$. However, the selected cultivar (Dijilla) gave the highest dry weight of both characters at high salinity condition when the PGR Kinetin was used as compared with the gibberellin and with those of local cultivar (Tamooze-2) at the same conditions (Tables 2 and 3). Both PGRs (Kinetin and Gibberellin) increased the growth of selected cultivar (Dijilla) more than the growth of local cultivar especially at high salinity condition, the inhibition of dry weight caused by salinity were alleviated when the plants were treated with PGR (Kinetin and Gibberellin), but Kinetin appeared to be the most effective in inducing the maximum dry weight at $16 \mathrm{ds}^{-1} \mathrm{~m}$.

Table 2. Effect of the interaction between salinity and growth regulator on shoots dry weight (g/pot) of the wheat cultivars.

\begin{tabular}{|c|c|c|c|c|c|c|c|}
\hline \multirow{4}{*}{ Cultivars } & \multicolumn{7}{|c|}{ Salinity levels $\left(\right.$ ds. $\left.^{-1} \mathrm{~m}\right)$} \\
\hline & $\mathbf{0}$ & & & 16 & & & \\
\hline & \multicolumn{7}{|c|}{ Plant Regulators Growth (PGR) } \\
\hline & control & kinetin & Gibberellin & Control & Kinetin & Gibberellin & mean \\
\hline Dijilla & 3.12 & 4.61 & 3.86 & 2.07 & 6.71 & 5.06 & 4.24 \\
\hline Tamooze-2 & 2.5 & 3.52 & 2.01 & 0.28 & 0.13 & 0.14 & 1.43 \\
\hline \multirow{2}{*}{ Mean } & 2.81 & 4.07 & 2.94 & 1.18 & 3.42 & 2.60 & \\
\hline & 3.27 & & & 2.40 & & & \\
\hline
\end{tabular}

L.S.D. (0.001):- Cultivar $=(0.448):$ Salt (0.448): $\mathrm{PGR}=(0.55):$ Cultivar $\times$ Salt $=(0.634):$ Cultivar $\times$ PGR $=(0.78):$ Salt $\times$ PGR $=(0.78):$ Cultivar $\times$ Salt $\times$ $\mathrm{PGR}=(1.10)$.

Table 3. Effect of the interaction between salinity and growth regulator on roots dry weight $\left(g .^{-1}\right.$ pot) of the wheat cultivars.

\begin{tabular}{|c|c|c|c|c|c|c|c|}
\hline \multirow{4}{*}{ Cultivars } & \multicolumn{6}{|c|}{ Salinity levels $\left(d s^{-1} \mathrm{~m}\right)$} & \\
\hline & $\mathbf{0}$ & & & 16 & & & \\
\hline & \multicolumn{7}{|c|}{ Plant Regulators Growth (PGR) } \\
\hline & control & kinetin & Gibberellin & Control & Kinetin & Gibberellin & Mean \\
\hline Dijilla & 1.30 & 2.8 & 1.68 & 0.65 & 4.06 & 2.68 & 2.20 \\
\hline Tamooze-2 & 0.94 & 1.29 & 0.53 & 0.03 & 0.02 & 0.01 & 0.47 \\
\hline \multirow{2}{*}{ Mean } & 1.12 & 2.05 & 1.11 & 0.34 & 2.04 & 1.35 & \\
\hline & 1.43 & & & 1.24 & & & \\
\hline
\end{tabular}

L.S.D. $(0.001)$ : - Cultivar $=(0.17):$ Salt $(\mathrm{P} \leq 0.05)(0.17): \mathrm{PGR}=(0.21):$ Cultivar $\times$ Salt $=(0.24):$ Cultivar $\times$ PGR $=(0.30):$ Salt $\times$ PGR $=(0.30):$ Cultivar $\times$ Salt $\times \operatorname{PGR}(\mathrm{P} \leq 0.05)=(0.23)$.

\subsection{Chlorophyll Content}

In relation to the control plants (non-saline treatment), salinized soil $\left(16 \mathrm{ds}^{-1} \mathrm{~m}\right)$ induced significant reduction $(\mathrm{P} \leq 0.01)$ in chlorophyll content in upper leaves of plants (Table 1). The content reduced from 34.28 (at non-saline condition) to 26.8 (at $16 \mathrm{ds}^{-1} \mathrm{~m}$ ) (Table 4). The cultivars differed significantly $(\mathrm{P} \leq 0.01)$ in their chlorophyll content and the PGRs also differed significantly $(\mathrm{P} \leq 0.01)$ in their effect on chlorophyll content of upper leaves (Table 1). However, the selected cultivar (Dijilla) has the highest chlorophyll content in their upper leaves as compared with local cultivar (Tamooze-2) (Table 4). This content with kinetin and Gibberellin or their interaction was differed significantly (Table 1). They enhanced the plant growth in stressed or unstressed, but in stressed condition $\left(16 \mathrm{ds}^{-1} \mathrm{~m}\right)$ were more effective than in non-saline condition $\left(0 \mathrm{ds}^{-1} \mathrm{~m}\right)$ especially in selected cultivar (Dijilla). At salinity treatment, there is no effect of PGR on chlorophyll content of local cultivar leaves (Table 4). The application of kinetin seems to be the most effective treatment in enhancing the chlorophyll production in upper leaves as compared with Gibberellin treatment especially at saline treatment (Table 4). But at saline treatment it was significant at both PGR treatments only in selected cultivar (Dijilla). 
Table 4. Effect of the interaction between salinity and growth regulator on chlorophyll of the wheat cultivars.

\begin{tabular}{|c|c|c|c|c|c|c|c|}
\hline \multirow{4}{*}{ Cultivars } & \multicolumn{6}{|c|}{ Salinity levels (ds. $\left.{ }^{-1} \mathrm{~m}\right)$} & \\
\hline & \multirow{2}{*}{\multicolumn{7}{|c|}{$\begin{array}{l}0 \\
\text { Plant Regulators Growth (PGR) }\end{array}$}} \\
\hline & & & & & & & \\
\hline & control & kinetin & Gibberellin & Control & Kinetin & Gibberellin & Mean \\
\hline Dijilla & 33.36 & 40.04 & 37.21 & 39.03 & 50.50 & 44.9 & 40.84 \\
\hline Tamooze-2 & 26.3 & 35.82 & 32.97 & 9.5 & 8.5 & 8.3 & 20.23 \\
\hline \multirow{2}{*}{ Mean } & 29.8 & 37.9 & 35.1 & 24.3 & 29.5 & 26.6 & \\
\hline & 34.28 & & & 26.8 & & & \\
\hline
\end{tabular}

L.S.D. (0.001):- Cultivar = (1.20): Salt (1.20): $\mathrm{PGR}=(1.47):$ Cultivar $\times$ Salt $=(1.7):$ Cultivar $\times$ PGR $=(2.08):$ Salt $\times$ PGR $=(2.08):$ Cultivar $\times$ Salt $\times$ PGR $(\mathrm{P} \leq$ $0.05)=(2.94)$.

\subsection{Salt tolerance Index}

The result in fig. 1 showed that the salt tolerance index of selected cultivar (Dijilla) was much higher than that of local cultivar. The salt tolerance index of Dijilla cultivar increased with application of kinetin and Gibberellinas compared with control treatment, while the results showed that there were no significant difference between the PGR treatment in their effect on the salt tolerance index of the local cultivar. Also the result indicated that the salt tolerance index of Dijilla cultivar more increased with application of kinetin as compared with application of Gibberellin (Fig.1) interestingly, the application of kinetin in the selected cultivar (Dijilla) increased salt tolerance index of this cultivar under saline conditions.

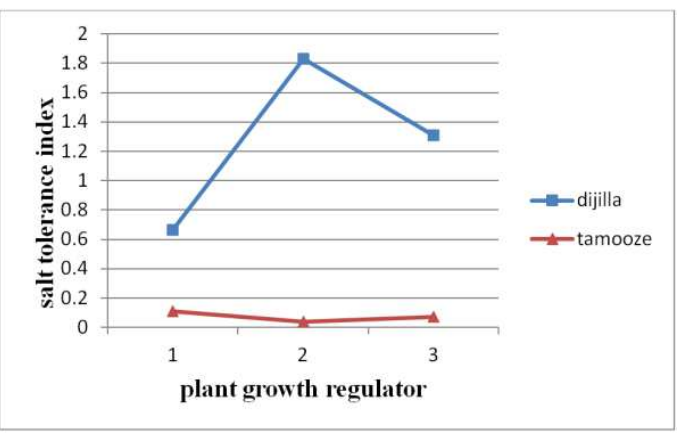

Fig. 1. Effect of application of Plant growth regulator on salt tolerance index in wheat cultivars grown under salinity conditions $\left(16 \mathrm{ds} .^{-1} \mathrm{~m}\right)$.

\subsection{Chlorophyll Stability Index}

Chlorophyll stability index in the selected cultivar was much higher than in the local cultivar (Tamooze-2) (Fig.2). Application of kinetin and Gibberellin under salinity condition increased the Chlorophyll stability index in the Dijilla cultivar, while they decreased this character in the local cultivar. Also the result showed that application of kinetin under salinity condition more effective than application of Gibberellin in their effect on chlorophyll stability index.

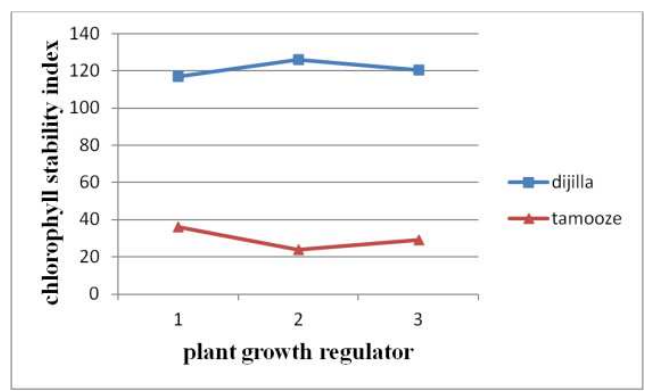

Fig. 2. Effect of application of Plant growth regulator on chlorophyll stability index in wheat cultivars grown under salinity condition $\left(16 d s^{-1} \mathrm{~m}\right)$.

\subsection{Organic Compound Percentage}

Organic compounds (carbon, lipid, total protein) in the leaves of selected cultivar (Dijilla) increased under salinity condition without application of PGR as compared with nonsaline condition (Table 5). Under salinity conditions, there are no values to organic compounds in the leaves of local cultivar because there is no growth of this cultivar under salinity condition. Under saline and non-saline condition, all the organic compounds increased when the PGRs were applied, but the increasing was much higher under saline condition as compared with non-saline condition. However, the Kinetin was more effective than Gibberellin in enhancing organic compounds in the leave, but it was much higher under salinity conditions. The lipid and protein compounds were increased more than carbon compound under salinity conditions with application of PGR, especially the Kinetin (Table 5).

Table 5. Effect of the interaction between salinity and plant growth regulators on organic compounds percentage of wheat cultivars.

\begin{tabular}{|c|c|c|c|c|c|c|c|c|c|c|c|c|}
\hline \multirow{6}{*}{ PGR } & \multicolumn{12}{|c|}{ Salinity levels } \\
\hline & \multicolumn{6}{|l|}{$\mathbf{0}$} & \multicolumn{6}{|l|}{16} \\
\hline & \multicolumn{6}{|c|}{ Cultivars } & \multicolumn{6}{|c|}{ Cultivars } \\
\hline & \multicolumn{3}{|c|}{ Dijilla } & \multicolumn{3}{|c|}{ Tamooze-2 } & \multicolumn{3}{|l|}{ Dijilla } & \multicolumn{3}{|c|}{ Tamooze-2 } \\
\hline & \multicolumn{6}{|c|}{ Organic compounds } & \multicolumn{6}{|c|}{ Organic compounds } \\
\hline & carbon & lipid & Prot. & carbon & lipid & Prot. & carbon & lipid & Prot. & carbon & lipid & Prot. \\
\hline Control & 8.92 & 0.79 & 1.90 & 7.90 & 0.20 & 1.32 & 12.45 & 5.45 & 2.67 & ---- & ---- & ---- \\
\hline Kinetin & 13.28 & 1.73 & 2.56 & 11.12 & 0.98 & 1.78 & 16.23 & 9.58 & 5.19 & ----- & ----- & ----- \\
\hline Gibberellin & 11.99 & 1.53 & 2.04 & 9.07 & 0.70 & 1.08 & 14.65 & 7.39 & 4.04 & ----- & ----- & ----- \\
\hline
\end{tabular}




\section{Discussion}

High salinity level was adversely affected plant growth (Tables 2 and 3 ) through its effect on water absorption by inducing a decrease in cellular permeability of water (20), and also through depresses meristematic activity and cell elongation and division (21). These effects were evidenced in the present study as the reduction in fresh mass of the salt stressed plants by $16 \mathrm{ds}^{-1} \mathrm{~m}$ of salinized soils as compared to the control $\left(0 \mathrm{ds}^{-1} \mathrm{~m}\right)$. Moreover, dry mass of the salinized plants was also decreased by $16 \mathrm{ds}^{-1} \mathrm{~m}$, may be as a results of the limited photosynthesis production (22) and of the reduction in numbers of leaves and tillers.

On the other hand, there are differences between the selected cultivar and local cultivar in the amount of reduction in shoots and roots dry weighs under salinity condition. However, the selected cultivar (Dijilla)less affected by salinity than local cultivar (Table 2, 3). Under these conditions, the response of the selected cultivar to the salinity was much higher than the response of local cultivar (Tamooze-2). These differences in their response refer to their differences in salt tolerance. On the other hand, the previous results reported that Dijilla cultivar more salt tolerance than local cultivar ( 8 and 11). Also the results of this study confirmed that the salt tolerance index of selected cultivar was much higher than those of the local cultivar (Tamooze-2), this mean that the salt tolerance of Dijilla cultivar much higher than Tamooze-2 (Fig.1). This improvement in salt tolerance in selected cultivar (Dijilla) may due to that this cultivar was selected from F2-F7, which generation generally contains a much wider range of genetic variation in salt tolerance after exposure of these materials to high salinity levels (30 ds. ${ }^{-1} \mathrm{~m}$ drainage water). This reflects that salt tolerant genes are segregated in these plants through the six cycles of screening and selection, and these genes exhibited expression for salt tolerance when grown in saline conditions (gene $\mathrm{x}$ environment interaction) (10). Clearly , this character is inherited (23 and 24), which reported that's the degree of inheritance depends on the genetic variation and salinity level. Therefore, the salt tolerance degree is correlated with the number and kind of salt tolerant genes which control the mechanisms of salt tolerance (25). On the other hands, some salt tolerant genes (TaGSK1, TaSC and TaSTK) have been detected in Dijilla cultivar only by using molecular studies with high expression under high salinity conditions (26; 27 and 28)

The superiority of selected cultivar (Dijilla) over the local one under high salinity level $\left(16 \mathrm{ds}^{-1} \mathrm{~m}\right)$ may associate with high chlorophyll content in the upper leaves (Table 4), which is important factor in photosynthetic and then determine the dry matter production (29 and 30). Increasing dry matter is very important in plant growth, tissues extension, and; yield and its components production. Under salinity conditions, increasing chlorophyll content in upper leaves of plant due to the modification in morphological characters as a mechanism to tolerate salt stress (31).
Plant growth and chlorophyll content enhancement with PGRs have been successfully applied to counteract the deleterious effects of salinity on plant growth (Tables 2, 3 and 4). Generally, plant growth was improved by application of kinetin and Gibberellin under salinity conditions only in selected cultivar (Dijilla) as compared with control (no PGR treatment), while at non-saline conditions the growth of both cultivars was increased as compared with control (no PGR treatment). Similarly Angrish et al. (32) reported that applied PGRs to reduce the adverse effects of salinity on germination and plant growth. From these results, kinetin was more effective than Gibberellin at both conditions. On other hand, they reported that cytokinins are important signaling molecules in plants (13) and interact with other plant hormones in the regulation of plant growth and development. Also Aldesuquy et al. (33) reported that kinetin was the most effective in increasing shoot dry weight and grain yield of cultivar under salt stress. It has been reported for a number of cultivars that salinity can reduce the cytokinins production and export from the root to the shoot (34). Therefore an adequate shoot cytokinin supply is essential for normal growth and development. The most effectiveness of kinetin to promote later plant growth and yield production because application of kinetin and gibberellin increase chlorophyll content and its stability in leaves (Fig. 2) which was very important for dry mass production and increasing yield and its components under salinity conditions. Accordingly, the result of this study (Fig. 1) showed that the kinetin and gibberellin increased salt tolerance index in plant especially in selected cultivar under salinity conditions as compared with those of the control (no PGRs treatment), but the kinetin more effective than gibberellins. This refers to the effect of kinetin and their interaction on leaf area, pigment content, photosynthetic activity, chloroplast ultra structure of flag leaf and controlling the distribution of dry mass in shoot to alleviate the damage induced by salinity. On the other hand, the inhibition of leaf area and number by salt stress was alleviated when the grains were soaked in kinetin (33). This recovery may due to the role of kinetin in increasing the rate of movement of nutrients and hormones from root toward the developing leaves, and thus increasing the rate of leaf expansion and activities. Therefore, all these processes improve the response of plant to the salinity and increase the salt tolerance degree. More studies are going to determine the best concentration and growth stage for application of plant growth regulation (Kinetin) to increase salt tolerance of plant. Under high salinity condition, the selected cultivar Dijilla was more salt tolerance than local cultivar (Tamooz-2) under high salinity (Fig 1), and it contained high organic compounds in their leaves (Table 5). This means that there was high correlation between the salt tolerance degree and organic compounds contents in the leaves. Because it would be essential to balance the osmotic pressure of the cell cytoplasm and also to allow turgor maintenance of cells that would otherwise dehydrate (35). In addition, they reported that their compounds could stabilize the membrane proteins 
and so maintain growth at high salinity levels. The benefit of these compounds on response of plant to salinity increased with application of plant growth regulators (PGR) under salinity condition. Therefore, application of PGR is very important factor for increasing salt tolerance in plant.

Generally, the conclusions of these results showed significant differences between selected cultivar (Dijilla) and local cultivar (Tamooze-2) in their salt tolerance and the high salt tolerance in selected cultivar was more correlated with high contents of chlorophyll and organic compounds in their upper leaves under high salinity conditions. Also application of Kinetin and Gibberellin are essential for increasing salt tolerance in plant under salinity conditions.

\section{References}

[1] Shu,S.; Yuan, Y. L.; Guo, S. R.; Sun, L. and Liu, G. (2012). Effects of exogenous spermidine on photosynthesis, xanthophyll cycle and endogenous polyamines in cucumber seedlings exposed to salinity. Afr. J. Biotechnol 1: 6064-6074.

[2] El-Nahry,A. H.and Hammad A.Y .(2009).Assessment of salinity effects and vegetation stress, West of Suez Canal, Egypt using remote sensing techniques. J. Appl. Sci. Res. 5: 316-322

[3] Aldesuquy,H. S. and Gaber, A. M. (1993). Effect of growth regulators on Vicia faba plants irrigated by seawater: leaf area, pigment content and photosynthetic activity. Biol. Plant. 35: 519-527.

[4] Ashraf , M. (2002).Salt tolerance of cotton: Some new advance, Plant Sci. 21(1), 1-30.

[5] Seckin,B.; Sekmen, A. H. and Turkan, I. (2009). An enhancing effect of exogenous mannitol on the antioxidant enzyme activities in roots of wheat under salt stress. J. Plant Growth Regul .28:12-20.

[6] Anuradha,S. and Rao, S. S. R. (2001). Effect of brassinosteroids on salinity stress induced inhibition of germination and seedling growth of rice (Oryza sativa L.). Plant Growth Regul., 33: 151-153.

[7] Tabur,S. and Demir, K. (2010). Role of some growth regulators on cytogenetic activity of barley under salt stress. Plant Growth Regul. 60: 99-104.

[8] Al-Mishhadani, I. I. H.; Abdula, K. H.; Ismail, E. N. Thahre, Y. D. and Weab, I. A. (2014).Estimation of new wheat genotypes for salt tolerance which induced through plant breeding programs. J. of Agric. Sci. and Technol.B. 4:150-156.

[9] Shannon, M. C. (1998). Adaptation of plants to salinity, Advn.Agron. 60, 75-119.

[10] Al-Mishhadani, I. I. H. (2012). Breeding and selection ofsome lines of bread wheat for salt tolerance, J. of Agric. Sci. and Technol. B. 2: 934-939.

[11] Al-Mishhadani, I. I. H. (2015).Genetic variation of salt tolerance character and organic components studies in selected salt tolerant genotype and sensetive cultivar of wheat. Global Journal of Science Frontier Research: E Interdiciplinary.15(2).
[12] Davies, P. J. (1995). The plant hormones: their nature, occurrence and functions. In: Plant Hormones. Ed. P. T. Davies, Kluwer Academic Publishers, Dordrech, 1-12.

[13] Rashotte, A. M.; Chae, H. S.; Maxwell, B. B.and Kieber, J. J. (2005). The interaction of cytokinin with other signals. Physiol .Plant. 123:184-194C.

[14] Swarup, R.; Parry, G.; Graham, N.; Allen, T. and Bennett, M. (2002). Auxin cross-talk: integration of signalling pathways to control plant development. Plant Mol. Biol. 49:411-426

[15] Biddington,N. L. and Thomas, T. H. (1976). Influence of different cytokinins on the germination of lettuce (Lactuca sativa) and celery (Apium graveolens) Seeds. Physiol .Plant .37:12-16.

[16] Gadallah, M. A. A. (1999). Effects of kinetin on growth, grain yield and some mineral elements in wheat plants growing under excess salinity and oxygen deficiency. Plant Growth Regul. 27:63-74

[17] Debez,A.; Chaibi, W. and Debez Bouzid, S. (2001). Effect of $\mathrm{NaCl}$ and growth regulators on germination of Atriplex halimus L. Cahiers Agric. 10:135-138

[18] Iqbal,M. and Ashraf, M. (2006). Wheat seed priming in relation to salt tolerance: growth, yield and levels of free salicylic acid and polyamines. Ann. Bot. Fennici 43(4).

[19] Lehmann, J.; Atzorn, R.; Bruckner, C.; Reinbothe, S.; Leopold, L.; Wasternack, C. and Parthier, B. (2000). Accumulation of jasmonate, abscisic acid, specific transcripts and proteins in osmotically stressed barley leaf segments. Planta. 197: 156-162.

[20] Mansour, M. M. F. and Stadelmann, E. J. (1994). $\mathrm{NaCl}$ induced changes in protoplasmic characteristics of Hordeum vulgare cultivars differing in salt tolerance. Physiol. Plant., 31: 29-41.

[21] Dorgham, E.A.(1991). Effect of water stress, irradiation and nitrogen fertilization on grain filling, yield and quality of certain wheat cultivars. Ph.D. Thesis. Ain Shams University of Cairo, Egypt.

[22] Munns, R., 2002. Comparative physiology of salt and water stress. Plant Cell Environ. 25: 239-250.

[23] Azhar, F. M. and Mc. Neilly T. (1989). Heritability estimates ofvariation for $\mathrm{NaCl}$ tolerance in Sorghum bicolor L., J.Agron. and Crop Sci. 43:69-72.

[24] Al-Mishhadani,I.I.H.;AL-shamma, A. M. and Attiya,H. J. (2003).Some genetic studies of salt tolerance in yield and its component of some selected genotypes of wheat, J. of Iraqi Agri. Sci. 34(2):111-118.

[25] Munns, R. (2005) Gene and salt tolerance, bringing them together, New Phytologist 167: 645-665.

[26] Ismail, E. N. (2013). Determination of gene expression of salt tolerant gene TaGSK1 in wheat cultivars, M.Sc. thesis, Baghdad University.

[27] Majeed, D. M.; Shwkat, M. S. and Sabbah, M. A. (2014). Determination of TaSC salt tolerance gene expression in selected wheat under different salt stresses. Egypt. Acad. J. Biolog. Sci. 5(1): 105-113.

[28] Ibrahim I. H Al-Mishhadani. (2015). Estimation of salt tolerance degree in some selected wheat genotypes by using detection of salt tolerant gene ( $T a S T K)$ and its expression under salinity conditions. Int. J. of Appl. Agric. Sci.1(2): 31-35. 
[29] Munns, R.(1993). Physiological processes limiting plant growth in saline soils, some dogmas and hypotheses, Plant Cell Environ. 16:15-24.

[30] Ashraf, M. (1994) Breeding for salinity tolerance in plant. City. Rev. Plant Sci.:13:17-42.

[31] Al-Mishhadani, I. I. H. (2010). Response of some newly developed salt-tolerant genotypes of wheat to naturally salinized soil. The 5th Int. Conf. for Develop and the Env. In the Arab World. Assisut University Center for Environmental Studies-Egypt.

[32] Angrish, R. Kumar, B. and Datta, K. S. (2001). Effect of gibberellic acid and kinetin on nitrogen content and nitrate reductase activity in wheat under saline conditions. Ind. J .Plant Physiol. 6:172-177

[33] Aldesuquy, H.; Baka, Z. and Mickky, B. (2014). Kinetin and spermine mediated induction of salt tolerance in wheat plants: Leaf area, photosynthesis and chloroplast ultrastructure of flag leaf at ear emergence. Egypt. J. of Basic. and Appl. Sci. 1: 7787.

[34] Kuiper,D.; Schuit, J. and Kuiper, P. J. C. (1990). Actual cytokinin concentrations in plant tissue as an indicator for salt resistance in cereals. Plant Soil 123:243-250

[35] Wyn Jones, R.G. and Lunt, O.R. (1967). The function of calcium in plants. Bot. Rev. 33.407-426. 